\title{
Amyloid $\beta$ peptide-induced inhibition of endothelial nitric oxide production involves oxidative stress-mediated constitutive eNOS/HSP90 interaction and disruption of agonist-mediated Akt activation
}

\author{
Folami Lamoke ${ }^{1 \dagger}$, Valeria Mazzone ${ }^{2 \dagger}$, Tiziana Persichini $^{2}$, Annamaria Maraschi $^{3}$, Michael Brennan Harris ${ }^{4}$, \\ Richard C Venema ${ }^{5}$, Marco Colasanti ${ }^{2}$, Micaela Gliozzi ${ }^{6}$, Carolina Muscoli, ${ }^{6,7}$, Manuela Bartoli ${ }^{1}$ and Vincenzo Mollace ${ }^{6,7^{*}}$
}

\begin{abstract}
Background: Amyloid $\beta$ (A $\beta$ )-induced vascular dysfunction significantly contributes to the pathogenesis of Alzheimer's disease (AD). A $\beta$ is known to impair endothelial nitric oxide synthase (eNOS) activity, thus inhibiting endothelial nitric oxide production (NO).
\end{abstract}

Method: In this study, we investigated Aß-effects on heat shock protein 90 (HSP90) interaction with eNOS and Akt in cultured vascular endothelial cells and also explored the role of oxidative stress in this process.

Results: Treatments of endothelial cells (EC) with A promoted the constitutive association of HSP90 with eNOS but abrogated agonist (vascular endothelial growth factor (VEGF))-mediated HSP90 interaction with Akt. This effect resulted in blockade of agonist-mediated phosphorylation of Akt and eNOS at serine 1179. Furthermore, A $\beta$ stimulated the production of reactive oxygen species in endothelial cells and concomitant treatments of the cells with the antioxidant $\mathrm{N}$-acetyl-cysteine (NAC) prevented A 3 effects in promoting HSP90/eNOS interaction and rescued agonist-mediated Akt and eNOS phosphorylation.

Conclusions: The obtained data support the hypothesis that oxidative damage caused by $A \beta$ results in altered interaction of HSP90 with Akt and eNOS, therefore promoting vascular dysfunction. This mechanism, by contributing to $A \beta$-mediated blockade of nitric oxide production, may significantly contribute to the cognitive impairment seen in AD patients.

\section{Introduction}

Alzheimer's disease (AD) is a progressive neurodegenerative disorder [1] characterized by the accumulation of intracellular neurofibrillary tangles and extracellular senile plaques of which the major component is the amyloid $\beta$ peptide $(A \beta)[2,3]$. Although the molecular mechanisms leading to neuronal damage in $\mathrm{AD}$ have not been completely understood, it is well established that increased

\footnotetext{
* Correspondence: mollace@libero.it

${ }^{\dagger}$ Equal contributors

'IRC-FSH, Department of Health Sciences, University of Catanzaro 'Magna Graecia', Catanzaro Complesso 'Ninì Barbieri', Roccelletta di Borgia 88021, Italy ${ }^{7}$ IRCCS San Raffaele Pisana, Via di Val Cannuta, 247, 00166 Rome, Italy Full list of author information is available at the end of the article
}

production of $A \beta$, in soluble and/or aggregate form, is a key causative event for $\mathrm{AD}[3,4]$.

A growing body of evidence has indicated that the cerebral vasculature is an important target of $A \beta$ and that vascular dysfunction significantly contributes to neuronal damage and dementia [5,6]. AD patients have reduced cerebral blood flow. This precedes dementia and may contribute to its progression. Recently, it has been shown that endothelin-1 is elevated in Alzheimer's disease and upregulated by amyloid $\beta$ [7]. Cardiovascular risk factors, especially hypertension, have been associated with higher risk of developing Alzheimer's disease, partially through cerebral vasculature impairment and reduced 
nitric oxide production [8]. The brains of patients with AD exhibit elevated levels of ACE, Ang-II, and angiotensin II receptors (AR-II) [9].

In addition, decreased endothelium-derived nitric oxide (NO) bioavailability and vascular dysfunction have been demonstrated in AD [10-15].

$\mathrm{NO}$ production at the endothelial cell level involves the activity of the enzyme endothelial nitric oxide synthase (eNOS, NOS III), which is constitutively expressed and produces $\mathrm{NO}$ in a calcium-dependent manner [16]. In models of chronic brain hypoperfusion, in vivo administration of $\mathrm{A} \beta$ has been shown to increase the expression of eNOS and, paradoxically, to decrease endothelium-derived NO formation [8], thus, suggesting that $A \beta$ could affect the activity of this enzyme. eNOS post-translational modification, including phosphorylation at specific amino acid residues, can profoundly affect its activity and, therefore, influence NO production [17]. Furthermore, eNOS association with a specific set of interacting proteins has been shown to critically regulate its enzymatic activity by exerting both stimulatory and/or inhibitory effects [18-21]. In particular, the chaperone molecule heat shock protein 90 (HSP90) has been demonstrated to possess a key stimulatory role by maintaining the enzyme in an active conformational state and by facilitating its phosphorylation at serine 1177/1179 [22-24]. A $\beta$ has been shown to inhibit eNOS phosphorylation at serine $1177 / 1179$ and at other residues $[25,26]$, however, no information is available about the effects of $A \beta$ on eNOS interaction with HSP90 or other regulatory partners, which could potentially contribute to these inhibitory effects. In addition, increased production of reactive oxygen species (ROS) and consequent oxidative stress have been shown to negatively influence eNOS activity and significantly contribute to vascular dysfunction in a number of cardiovascular diseases including diabetes and hypertension [23-30]. A $\beta$-induced oxidative stress has been extensively documented [31-33]; however, its direct contribution to the reported effects in inhibiting eNOSdependent NO production or in influencing its interaction with regulatory proteins is not clear.

In this study, we show that in bovine aortic endothelial cells soluble $A \beta_{1-42}$ promotes the constitutive association of HSP90 with eNOS. This effect resulted in blockade of agonist-mediated phosphorylation of Akt and eNOS at serine 1179. These effects are correlated with A $\beta$ 's ability to increase the production of hydroxyl radicals in endothelial cells and are reverted by concomitant treatment with the antioxidant $\mathrm{N}$-acetyl-cysteine.

\section{Materials and methods Materials}

All tissue culture reagents were from Invitrogen (Carlsbad, CA, USA), unless otherwise specified. Fetal bovine serum (FBS) was from Gemini Bio-products (Woodland, CA,
USA). $A \beta_{25-35}, A \beta_{35-25}, A \beta_{1-42}$, and $A \beta_{42-1}$ peptides, as well as nitro-L-arginine methyl ester (L-NAME), were from Sigma-Aldrich (St. Louis, MO, USA). Monoclonal and polyclonal anti-eNOS and anti-HSP90 antibodies were from BD-Transduction Laboratories (San Diego, CA, USA). The polyclonal antibody for phospho-eNOS (Ser 1179) was from Invitrogen (Grand Island, NY, USA). Polyclonal and monoclonal antibodies for anti-Akt and phospho-Akt (Ser473) were purchased from Cell Signaling (Danvers, MA, USA). Protein A/G agarose beads were from Santa Cruz Biotechnology (Santa Cruz, CA, USA). The ECL chemiluminescence detection assay as well as the peroxidase-conjugated anti-mouse/anti-rabbit IgG were from Amersham Biosciences (Piscataway, NJ, USA). The cGMP enzyme-immunoassay kit was from Cayman Chemical Co. (Ann Arbor, MI, USA). The blots were reprobed after stripping using a stripping solution from Pierce (Rockford, IL, USA).

\section{Cell cultures and treatments conditions}

Primary cultures of bovine aortic endothelial cells (BAEC) and brain endothelial cells (BBEC) were purchased from VEC Technologies (Rensselaer, NY, USA) or the endothelial cell Core Facility of the Vascular Biology Center at Georgia Regents University. BAEC were cultured in medium M199 in the presence of $10 \% \mathrm{FBS}, 1 \%$ glutamine, $1 \%$ penicillin/ streptomycin, and $1 \%$ non-essential amino acid and vitamin mixtures. The cells were used between passages 3 and 5. Oligomeric preparations of $\mathrm{A} \beta$ peptides (25-35, $35-25,1-42$, or $42-1$ ) were prepared by re-suspension in serum-free medium, left overnight at room temperature, then sonicated before supplementation to the culture medium as described previously [34].

The cells were pretreated for $24 \mathrm{~h}$ with $1 \mu \mathrm{M} \mathrm{A} \beta_{25-35}$, $1 \mu \mathrm{MA} \beta_{35-25}, 5 \mu \mathrm{MA} \beta_{1-42}$, and $5 \mu \mathrm{MA} \beta_{42-1}$. These doses of $A \beta$ and the time of exposure were chosen based on preliminary experiments testing maximal effects (data not shown). After pre-incubation the cells were stimulated with $20 \mathrm{ng} / \mathrm{ml}$ vascular endothelial growth factor (VEGF) for established time points. Rat aortic smooth muscle cells (RASMC) were also obtained from VEC Technologies and used between passages 2 to 5 for the cGMP experiments. The RASMC cultures were maintained in DMEM (Invitrogen, Grand Island, NY, USA) containing $10 \% \mathrm{FBS}$ and $1 \%$ penicillin/streptomycin.

\section{Nitric oxide production}

Nitric oxide release in BAEC was measured by cGMP reporter cell assay following a protocol modified from Ishii et al. [35,36]. Confluent BAEC and RASMC were serum-starved for 16 to $18 \mathrm{~h}$ and then incubated in Locke's buffer ( $154 \mathrm{mM} \mathrm{NaCl}, 5.6 \mathrm{mM} \mathrm{KCl}, 2 \mathrm{mM} \mathrm{CaCl}$, $1 \mathrm{mM} \mathrm{MgCl} 2$, and $10 \mathrm{mM} \mathrm{Hepes,} \mathrm{pH} 7.4$ ) for at least $20 \mathrm{~min}$ before the experiment. The BAECs were then 
stimulated with $20 \mathrm{ng} / \mathrm{ml}$ VEGF for $30 \mathrm{~min}$ and, after stimulation, the bathing medium was rapidly transferred to the confluent RASMC, let incubate for $3 \mathrm{~min}$, then the cells were lysed in ice-cold 20-mM sodium acetate, $\mathrm{pH}$ 4.0. The cGMP concentration in RASMC treated with the BAEC conditioned medium was determined using an enzyme immunoassay kit following the manufacturer's instructions.

\section{Determination of reactive oxygen species formation}

The production of reactive oxygen species in endothelial cells, following the different treatments, was determined by a fluorimetric assay using 2,7-dihydrochlorofluorescein (DHCF) from Invitrogen (Grand Island, NY, USA). BAEC, and BBEC plated in 96-well plates, were cultured for $24 \mathrm{~h}$ in serum-free condition and in presence or absence of $A \beta$. After this time, the cells were incubated with $5 \mu \mathrm{M}$ DHCF for $1 \mathrm{~h}$. The hydroxyl radicals produced in response to the different treatments oxidize the DHCF and generate its oxidation fluorescent product dichlorofluorescein (DCF). The fluorescence intensity was measured with a multi-detection microplate reader (BioTek, Winooski, VT, USA) using an excitation and emission light at $485 \mathrm{~nm}$ and $535 \mathrm{nM}$, respectively. Some samples were also incubated in the presence of $50 \mathrm{U}$ of cell permeable superoxide dismutase (PEG-SOD from Sigma-Aldrich, Saint Louis, MO, USA), which was used as negative control to assess the specificity of the assay.

\section{Immunoprecipitation and Western blotting}

Western blotting analysis was performed as previously described [37,38]. Briefly, BAEC and BBEC were lysed with a modified RIPA buffer ( $20 \mathrm{mM}$ Tris- $\mathrm{HCl}$ ( $\mathrm{pH} 7.4)$, $2.5 \mathrm{mM}$ EDTA, $50 \mathrm{mM} \mathrm{NaF}, 10 \mathrm{mM} \mathrm{Na}_{4} \mathrm{P}_{2} \mathrm{O}_{7}, 1 \%$ Triton $\mathrm{X}-100,0.1 \%$ sodium dodecyl sulphate, $1 \%$ sodium deoxycholate, $1 \mathrm{mM}$ PMSF, and $\left.2 \mathrm{mM} \mathrm{Na}_{3} \mathrm{VO}_{4}\right)$. The samples were then subjected to SDS-PAGE electrophoresis and immunoblotted on nitrocellulose (Schleicher \& Schuell Biosciences Inc., Keene, NH, USA). Protein-protein interaction was determined by immunoprecipitation analysis performed as previously described [37,38]. For these experiments, the cells were lysed with a buffer containing: $25 \mathrm{mM}$ Tris- $\mathrm{HCl}$ (pH 7.4), $2.5 \mathrm{mM}$ EDTA, $50 \mathrm{mM} \mathrm{NaF}$, $10 \mathrm{mM} \mathrm{Na}_{4} \mathrm{P}_{2} \mathrm{O}_{7}, 1 \%$ Triton X-100, $1 \mathrm{mM}$ PMSF, and $2 \mathrm{mM} \mathrm{Na}_{3} \mathrm{VO}_{4}$. The cell lysates were allowed to react overnight with the primary antibody and the immunocomplexes were then precipitated with pre-cleared protein A/ $\mathrm{G}$ agarose beads. After washing three times with ice-cold washing buffer $(0.1 \%$ Triton X-100 in TBS) the beads and the immunocomplexes were precipitated by centrifugation, solubilized by resuspension in 2X SDS-sample buffer and by boiling at $100^{\circ} \mathrm{C}$ for $5 \mathrm{~min}$. All the densitometry units have been normalized against total enzyme for each lane and are expressed as the ratio of phosphorylated proteins to total.

\section{Results}

A $\beta$ blocks eNOS phosphorylation at serine 1179 and eNOS-dependent NO production

We selected two amyloid $\beta$ peptides to conduct our experiments: $A \beta_{25-35}$, the shortest fibrillar fragment typically used in culture based on its capability of retaining the toxicity of the full length $A \beta(1-40 / 42)$ peptides [39], and $A \beta_{1-42}$, the disease-associated fragment found in patients with AD [40]. BAEC were cultured for $24 \mathrm{~h}$ in the presence of $10 \mu \mathrm{MA} \beta_{25-35}$ or $5 \mu \mathrm{MA} \beta_{1-42}$ and then challenged with $20 \mathrm{ng} / \mathrm{ml}$ VEGF for different time points $(0,5,15$, and $30 \mathrm{~min})$. Figure $1 \mathrm{~A}, \mathrm{~B}$ shows the Western blotting analysis determining phospho-serine 1179-eNOS formation in response to VEGF stimulation in BAEC cultured in the presence or absence (control) of $A \beta_{25-35}$ (Figure $1 \mathrm{~A}$ ) or $\mathrm{A} \beta_{1-42}$ (Figure 1B). Densitometric analysis was used to quantify the obtained data and to assess statistical significance of the results (Figure 1A,B). VEGF induced a time-dependent increase in eNOS phosphorylation at serine 1179 in control cells, but this effect was completely blocked by the pre-treatment of the cells for 24 h with $10 \mu \mathrm{MA} \beta_{25-35}$ or $5 \mu \mathrm{MA} \beta_{1-42}$. To test for the specificity of inhibitory activities of $A \beta_{25-35} / A \beta_{1-42}$ on phosphorylation of eNOS, BAEC were treated with the reversed inactive peptides $A \beta_{35-25}$ (Figure $1 C$ ) and $A \beta_{42-1}$ (Figure 1D). As shown in Figure 1C,D, VEGF-induced eNOS phosphorylation at serine 1179 was unaffected by the treatment with $A \beta_{35-25}$ or $A \beta_{42-1}$, thus proving that eNOS inhibition was specifically elicited by the $A \beta_{25-35}$ and $A \beta_{1-42}$ sequence derived from the amyloid precursor protein. Next, to establish whether $A \beta_{25-35} / A \beta_{1-42}$ effects on serine 1179 phosphorylation resulted in impairment of eNOS activity, we evaluated cGMP formation as a measure of NO production by eNOS in a cell reporter assay. The obtained data are summarized in Figure 1E. The treatment with $A \beta_{25-35}$ or $A \beta_{1-42}$ reduced the amount of cGMP generated by RASMC incubated with the BAEC-conditioned medium by over $80 \%(P<0.05$, $n=4$ ) (Figure $1 \mathrm{E}$ ). This latter directly correlates with the amount of NO generated by the BAEC in response to VEGF stimulation. To control for the specificity of the cGMP assay, some BAEC cells were incubated in the presence of $100 \mu \mathrm{M}$ of NOS inhibitor L-NAME before VEGF stimulation (Figure 1E). These data showed that the pretreatment of BAEC with L-NAME prevented an accumulation of cGMP in RASMC. The incubation of BAEC pre-treated with $A \beta_{25-35}$ and $A \beta_{1-42}$ with L-NAME resulted in further decrease in cGMP formation in RASMC (Figure 1E) suggesting that multiple signaling pathways contribute to eNOS activation by VEGF. 

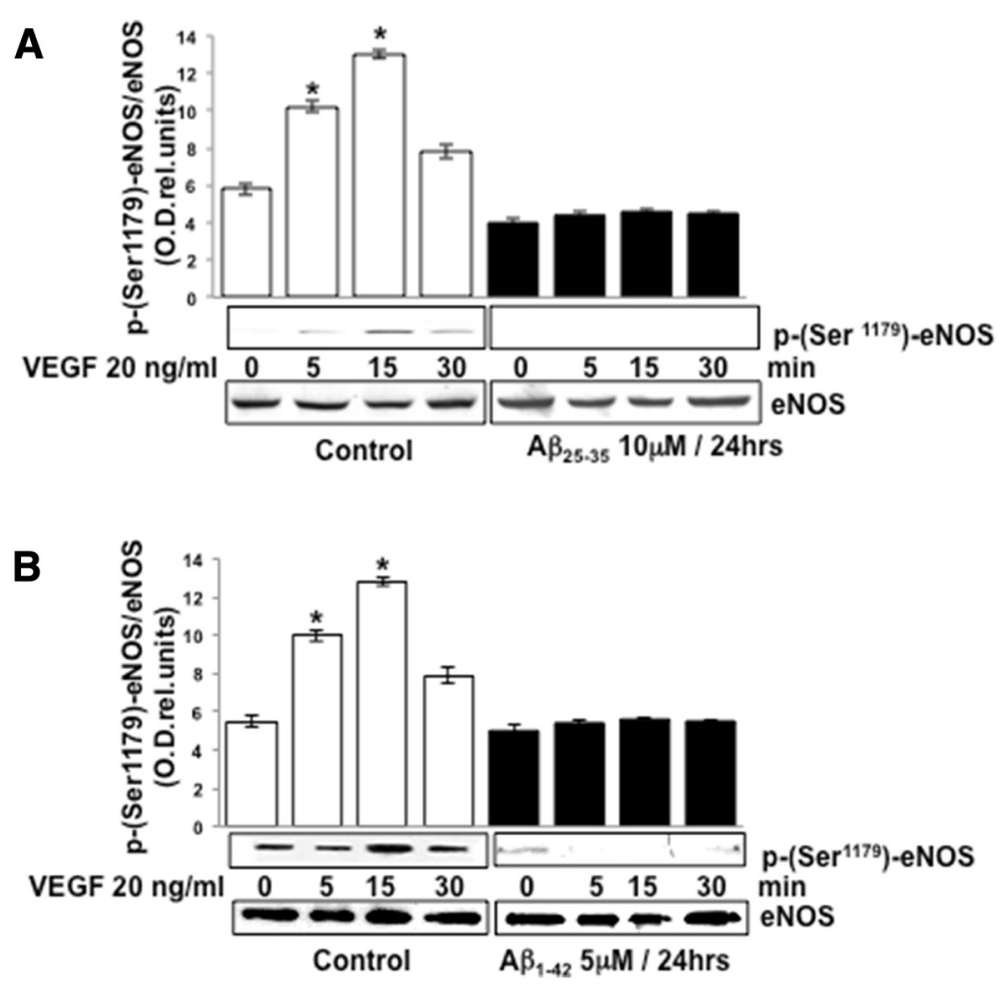

C

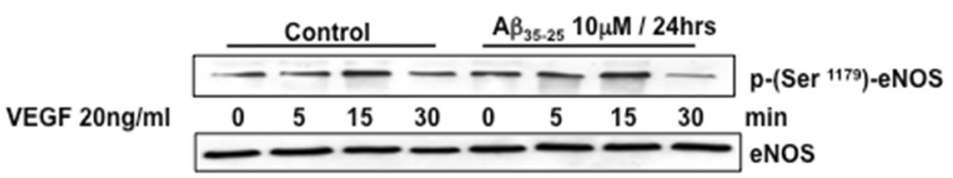

D

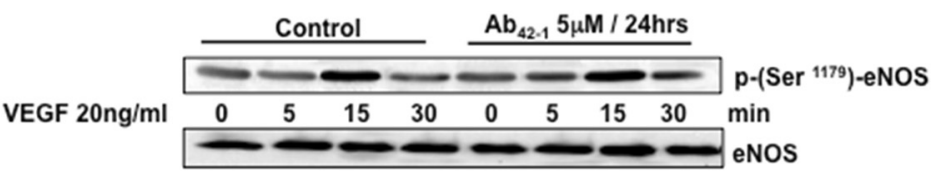

E

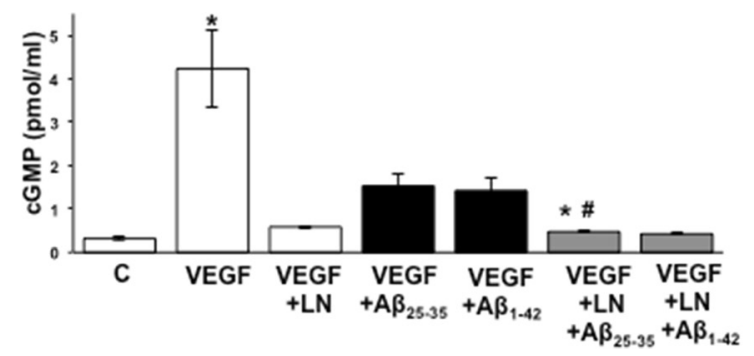

Figure 1 (See legend on next page.) 
(See figure on previous page.)

Figure 1 Western blotting analysis showing VEGF-stimulated (20 ng/ml for 0 to $30 \mathrm{~min}$ ) eNOS phosphorylation at serine 1179 in BAECs cultured for $24 \mathrm{~h}$ in the presence (black bars) or absence (control, white bars) of $10 \mu \mathrm{M} \mathrm{A} \beta_{25-35}$ (A) and $5 \mu \mathrm{M} A \beta_{1-42}$ (B). Blots were subjected to densitometric analysis and the obtained data were analyzed for statistical significance ${ }^{*} P<0.01$ versus 0 min control group, $\left.n=3\right)$. (C-D) Western blotting analysis demonstrating VEGF-stimulated eNOS phosphorylation at serine $1179 \mathrm{in}$ BAECs cultured for $24 \mathrm{~h}$ in the presence of reversed inactive $10 \mu \mathrm{M}$ $A \beta_{35-25}(\mathbf{C})$ and $5 \mu \mathrm{MA} \beta_{42-1}$ (D). (E) Endothelial nitric oxide release. cGMP formation in BAECs cultured for $24 \mathrm{~h}$ in the presence (black bars) or absence (white bars) of $10 \mu \mathrm{MA} \beta_{25-35}$ and $5 \mu \mathrm{MA} \beta_{1-42}$ and following stimulation with $20 \mathrm{ng} / \mathrm{ml} \mathrm{VEGF}$ for 30 min. cGMP formation, which directly reflects the nitric oxide release, was determined by reporter cell assay by measuring picomoles of cGMP generated in rat aortic smooth muscle cells after 3 min of exposure of the cells to media of BAECs after the different treatments, as indicated above and as explained in the text. To assess the assay specificity, some experiments were conducted with BAECs pre-stimulated with $100 \mu \mathrm{M}$ of the nitric oxide synthase inhibitor $L-N A M E$ (LN). ${ }^{*} P<0.05$ versus control, $n=4, \# P<0.05$ versus VEGF, $n=4)$. VEGF, vascular endothelial growth factor; eNOS, endothelial nitric oxide synthase; min, minutes.

\section{A $\beta$ stimulates constitutive eNOS/HSP90 complex formation}

eNOS activity is also influenced by its interaction with a specific set of regulatory proteins. Therefore, it is possible that $\mathrm{A} \beta$ peptides could alter the process of eNOS interaction with its regulatory partners. We tested this possibility and focused our attention on the chaperone molecule HSP90. In Figure 2, the results of the immunoprecipitation study assessing HSP90/eNOS complex formation are summarized. Specific immunoreactivity for HSP90 found in the protein complex immunoprecipitated by anti-eNOS antibody was increased in response to VEGF stimulation, thus indicating that VEGF stimulation of BAEC promoted the interaction of HSP90 with eNOS. This interaction, which peaked at 15 and $30 \mathrm{~min}$ after VEGF treatment (Figure 2A,B), was enhanced by the pretreatment for 24 h with $10 \mu \mathrm{M} \mathrm{A} \beta_{25-35}$ and $5 \mu \mathrm{M} \mathrm{A} \beta_{1-42}$ and was also induced at the basal level as compared to untreated control cells ( 0 min on Figure $2 \mathrm{~A}, \mathrm{~B})$, thus suggesting that $\mathrm{A} \beta$ promotes the formation of eNOS/HSP90 complex in a constitutive manner. Consistently, specific immunoreactivity for eNOS was detected in response to VEGF treatment in a time-dependent manner in the protein complex immunoprecipitated by anti-HSP90 antibody (Figure $2 \mathrm{C}, \mathrm{D})$. The pre-treatment with either $\mathrm{A} \beta$ promoted eNOS/HSP90 interaction at the basal level (0 min) and further stimulated eNOS/HSP90 complex formation after stimulation with VEGF (Figure 2C,D).

\section{$A \beta$ stimulates reactive oxygen species production}

$\mathrm{A} \beta$ has been shown to promote reactive oxygen species production and oxidative stress in vivo and in vitro. At the same time, oxidative damage has been involved in impairment of eNOS-dependent NO production and vascular dysfunction. To test the hypothesis that oxidative stress could be involved in $\mathrm{A} \beta$ effects on eNOS phosphorylation pattern or its interaction with HSP90, we first determined $\mathrm{A} \beta_{25-35} / \mathrm{A} \beta_{1-42}$ effects on production of superoxide anion in endothelial cells. Figure 3 illustrates the results obtained from a fluorimetric analysis measuring dichlorofluorescein

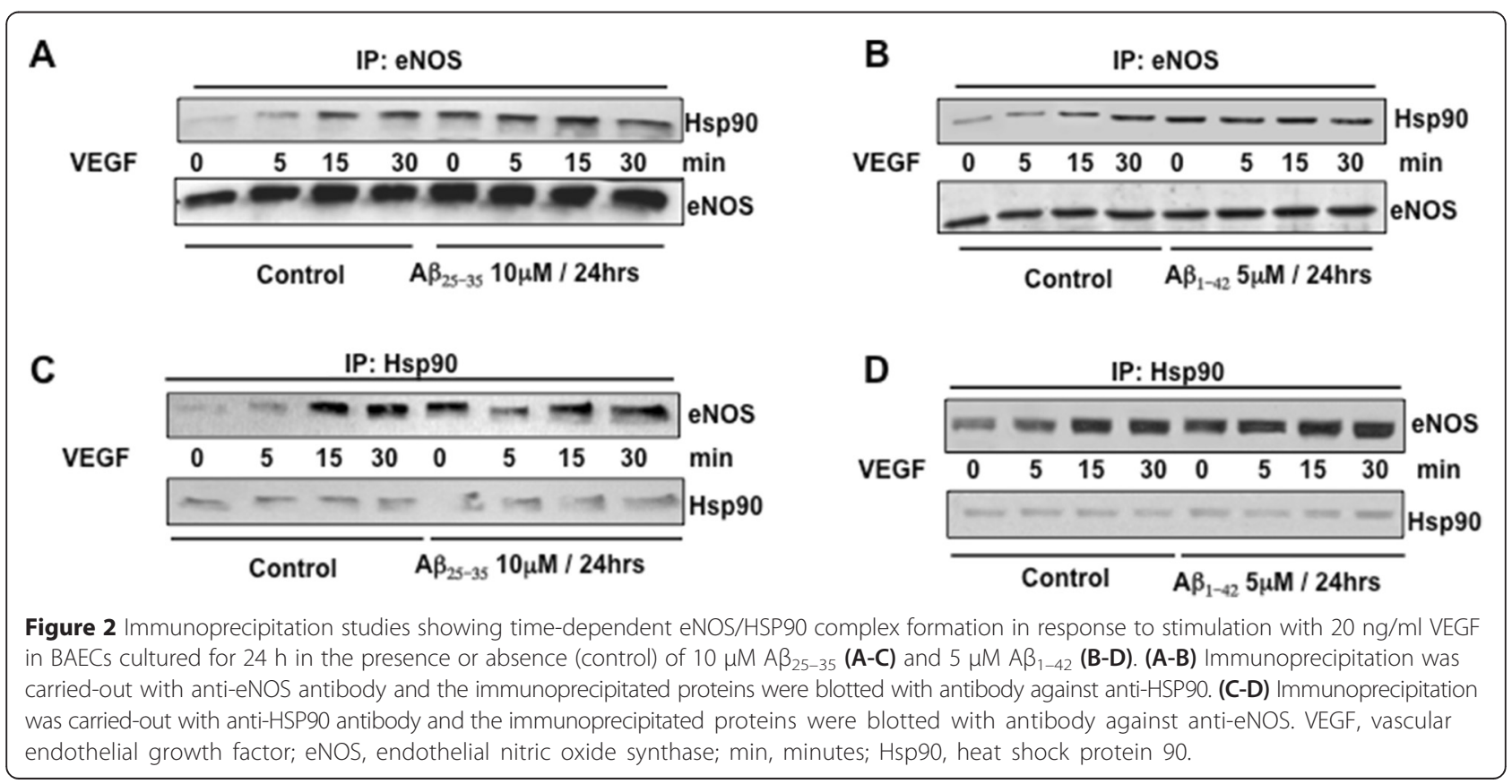




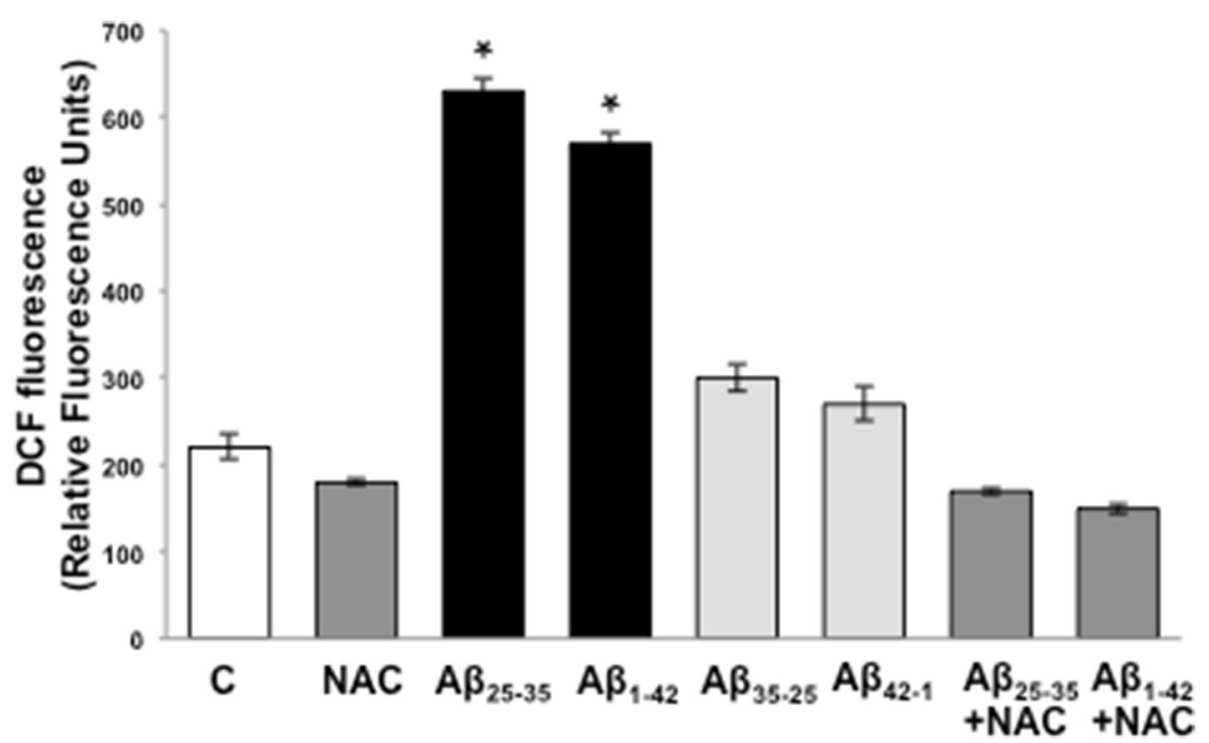

Figure 3 Effects of $A \beta$ peptides $\left(A \beta_{25-35} / A \beta_{1-42}=\right.$ active, $A \beta_{35-25} / A \beta_{42-1}=$ reverse, inactive) on superoxide anion production in $B A E C s$ assessed by dichloro-dihydrofluoresceindiacetate (DHCF-DA) fluorimetric assay. Some samples were pre-treated with $2 \mathrm{mM}$ of the anti-oxidant $\mathrm{N}$-acetyl-cysteine (NAC) to determine assay specificity. ( ${ }^{*} P<0.001$ versus control, $n=6$ ).

(DCF) formation in BAEC cultured for $24 \mathrm{~h}$ in the presence of $10 \mu \mathrm{MA} \beta_{25-35}$ or $5 \mu \mathrm{MA} \beta_{1-42}$ in comparison to BAEC cultured in the presence of an equivalent dose of the reverse peptides $A \beta_{35-25}$ and $A \beta_{42-1}$ or control BAEC cultured in normal medium in the absence of $A \beta$. The conversion of 2,7-dihydrochlorofluorescein (DCHF) to the fluorescent compound dichlorofluorescein (DCF) is directly correlated to the amount of superoxide and hydroxyl radicals generated in the cells. $A \beta_{25-35}$ and $A \beta_{1-42}$ caused twofold increase $(P<0.001, n=6)$ in ROS formation as compared with control BAEC, but this effect was not observed in cells cultured in the presence of the reversed inactive peptides $A \beta_{35-25}$ or $A \beta_{1-42}$ (Figure 3). In addition, $\mathrm{A} \beta_{25-35} / \mathrm{A} \beta_{1-42}$ induced ROS production was inhibited by the concomitant treatment of the cells with $2 \mathrm{mM}$ of the antioxidant $\mathrm{N}$-acetyl-cysteine (NAC), confirming the specificity of the fluorescent signal.

\section{$A \beta$ effects on eNOS phosphorylation are blocked by $\mathrm{N}$-acetyl cysteine}

Because of the observed ability of $A \beta_{25-35} / A \beta_{1-42}$ to augment the production of ROS in endothelial cells, we further tested whether antioxidants could prevent the effects of $A \beta_{25-35}$ and $A \beta_{1-42}$ in altering eNOS phosphorylation/activation pattern. BAEC were cultured for 24 h with $10 \mu \mathrm{MA} \beta_{25-35}$ or $5 \mu \mathrm{M} \mathrm{A} \beta_{1-42}$ in the presence or absence of $2 \mathrm{mM}$ NAC. Western blotting analysis was then conducted to determine the phosphorylation of eNOS at serine 1179 in response to stimulation with $20 \mathrm{ng} / \mathrm{ml} \mathrm{VEGF}$ for 5, 15, and $30 \mathrm{~min}$ (Figure 4). As shown in Figure 4A,B, NAC treatment restored a normal pattern of eNOS phosphorylation at serine 1179 following
VEGF stimulation, thus abolishing the inhibitory effect of $\mathrm{A} \beta_{25-35}$ and $\mathrm{A} \beta_{1-42}$. Densitometric analysis of the obtained results is plotted in Figure 4C,D where these data are compared to those shown in Figure $1 \mathrm{~A}, \mathrm{~B}$ to assess statistical significance.

\section{NAC disrupts enhanced eNOS/HSP90 association by $A \beta$}

Next then we determined the effects of the antioxidant NAC on $A \beta_{25-35} / A \beta_{1-42}$ induction of eNOS/HSP90 complex formation. As in the previous experiments (Figure 2) and as shown in Figure 5, treatment of the BAEC with NAC prevented the ability of $A \beta_{25-35}$ (Figure $5 \mathrm{~A}, \mathrm{C}$ ) and $\mathrm{A} \beta_{1-42}$ (Figure 5B,D) to promote HSP90/eNOS complex formation under basal conditions $(0 \mathrm{~min})$ and also restored an association pattern similar to that induced by VEGF in BAEC cultured under normal conditions without $\mathrm{A} \beta_{25-35}$ or $\mathrm{A} \beta_{1-42}$.

\section{$A \beta$ inhibits VEGF-stimulated Akt phosphorylation at Ser473 and Akt/eNOS interaction}

It is known that VEGF activation stimulates the protein kinase, Akt, and its subsequent phosphorylation/activation leads to the eNOS phosphorylation at Ser1179 [41] as detected in Figure 1. To determine whether $A \beta$ affected the signaling cascade of Akt, we first investigated the effects of $A \beta$ on Akt-Ser ${ }^{473}$ phosphorylation (Figure 6). As expected, VEGF significantly increased the phosphorylation of Akt-Ser473 in control cells. The phosphorylation of Akt peaked from 5 to $15 \mathrm{~min}$ and after $30 \mathrm{~min}$ was undetectable (Figure 6). The addition of $\mathrm{A} \beta_{25-35}$ (Figure 6) or $A \beta_{1-42}$ (Figure $6 \mathrm{~B}$ ) resulted in the complete interruption in the sequential phosphorylation of Akt, which 


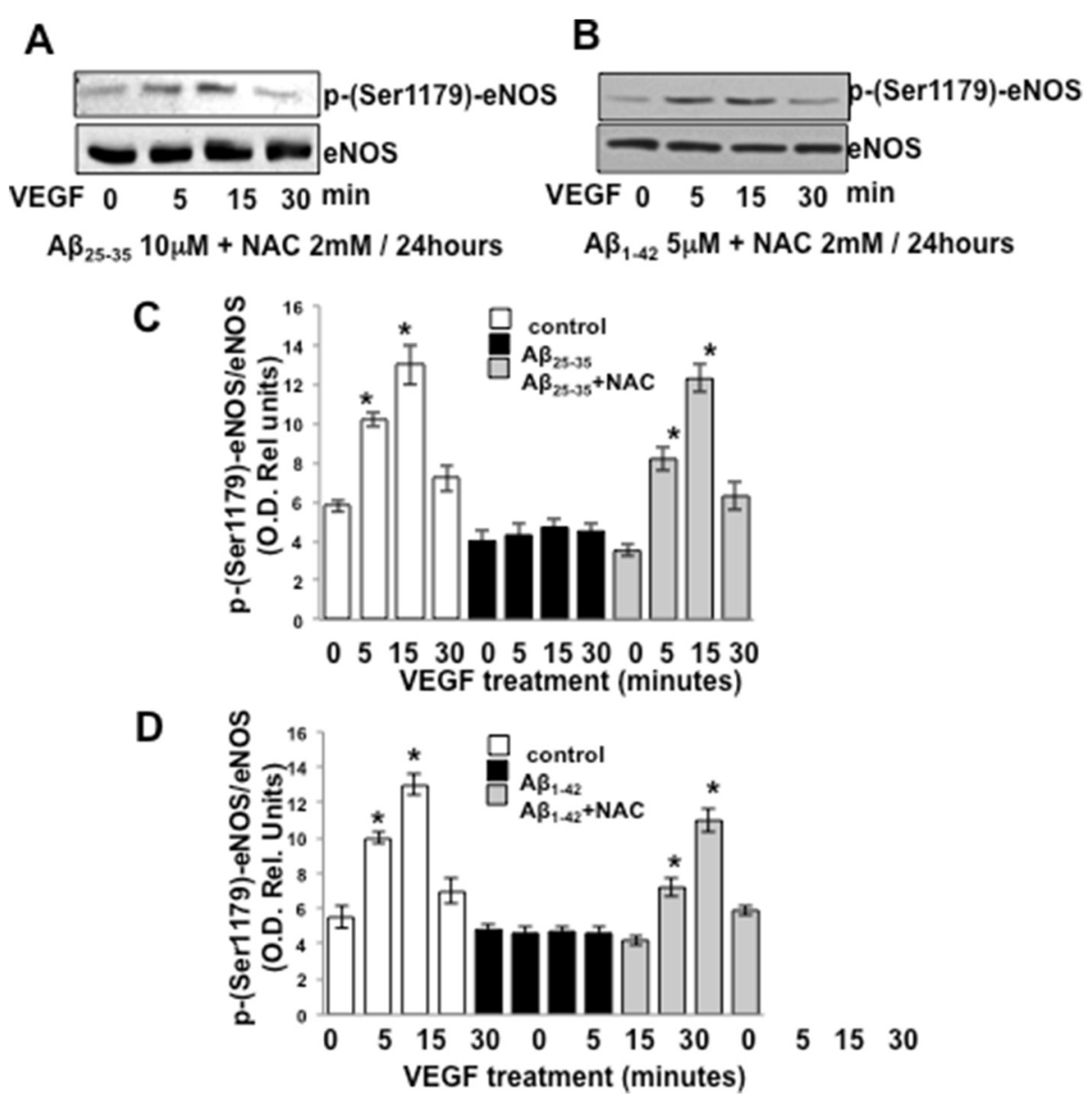

Figure 4 Representative Western blotting showing phosphorylation of eNOS at serine 1179 in response to stimulation with $20 \mathrm{ng} / \mathrm{ml}$ VEGF of BAECs cultured for $24 \mathrm{~h}$ in the presence of $10 \mu \mathrm{MA} \beta_{25-35}$ (A) or $5 \mu \mathrm{M} A \beta_{1-42}$ (B) in combination with 2 mM NAC. (C-D) The blots were subjected to densitometric analysis, and the obtained data were analyzed for statistical significance in comparison to the data shown in Figure $1 A, B$. $\left({ }^{*} P<0.05\right.$ versus 0 min of each separate treatment group, $\left.n=3\right)$. VEGF, vascular endothelial growth factor; eNOS, endothelial nitric oxide synthase; min, minutes; NAC, N-acetyl-cysteine.

occurred in parallel to the disruption of eNOS activation observed previously (Figure 1A,B,E). Concurrently, we identified specific immunoreactivity for Akt in the protein complex immunoprecipitated by an anti-eNOS antibody which increased in response to VEGF stimulation (Figure 7A,B). This interaction peaked at $5 \mathrm{~min}$ after VEGF stimulation but was lost with the pre-treatment with $\mathrm{A} \beta_{25-35}$ (Figure 7A) and $\mathrm{A} \beta_{1-42}$ (Figure 7B) for $24 \mathrm{~h}$. Consistent with those data, specific immunoreactivity for eNOS was detected in the protein complex immunoprecipitated by anti-Akt antibody after $5 \mathrm{~min}$ of VEGF stimulation (Figure 7C,D). The pre-treatment with either $A \beta$ led to the loss of eNOS/Akt interaction. Obtained results validate that VEGF stimulation of BAEC promotes the interaction of Akt with eNOS and suggest that $\mathrm{A} \beta$-induced blockade of eNOS activity and NO production involves the alteration in Akt/eNOS regulation.

\section{NAC recovers $A \beta$-induced Akt phosphorylation}

We examined the effects of NAC on Akt phosphorylation at Ser473 by Western blotting when stimulated with $20 \mathrm{ng} / \mathrm{ml}$ VEGF for 5, 15, and $30 \mathrm{~min}$. Treatment with the antioxidant NAC re-established the previously identified pattern of Akt phosphorylation following VEGF stimulation (Figure 8A,B). To assess statistical significance, the densitometric analysis data are compared to those shown in Figure 6A,B and the obtained results are plotted in Figure 8C,D.

\section{$A \beta$ perturbs Akt/HSP90 association}

The replacement of HSP90 with its associated proteins can be critical to the regulation of those proteins, as demonstrated in studies that showing that nitrated lipid, OLA- $\mathrm{NO}_{2}$, enhances eNOS/Hsp90 interaction by replacing the eNOS/cav1 interaction, resulting in increasing eNOS activity [42]. We sought to determine whether an $\mathrm{A} \beta$-induced augmentation of eNOS/HSP90 had an 
A

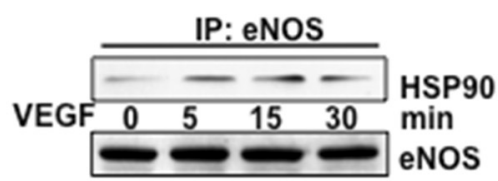

$A \beta_{25-35} 10 \mu M+N A C 2 m M / 24$ hours

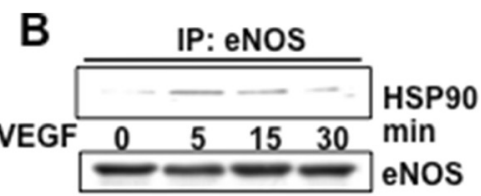

$A \beta_{1-42} 5 \mu M+N A C 2 m M / 24$ hours

C
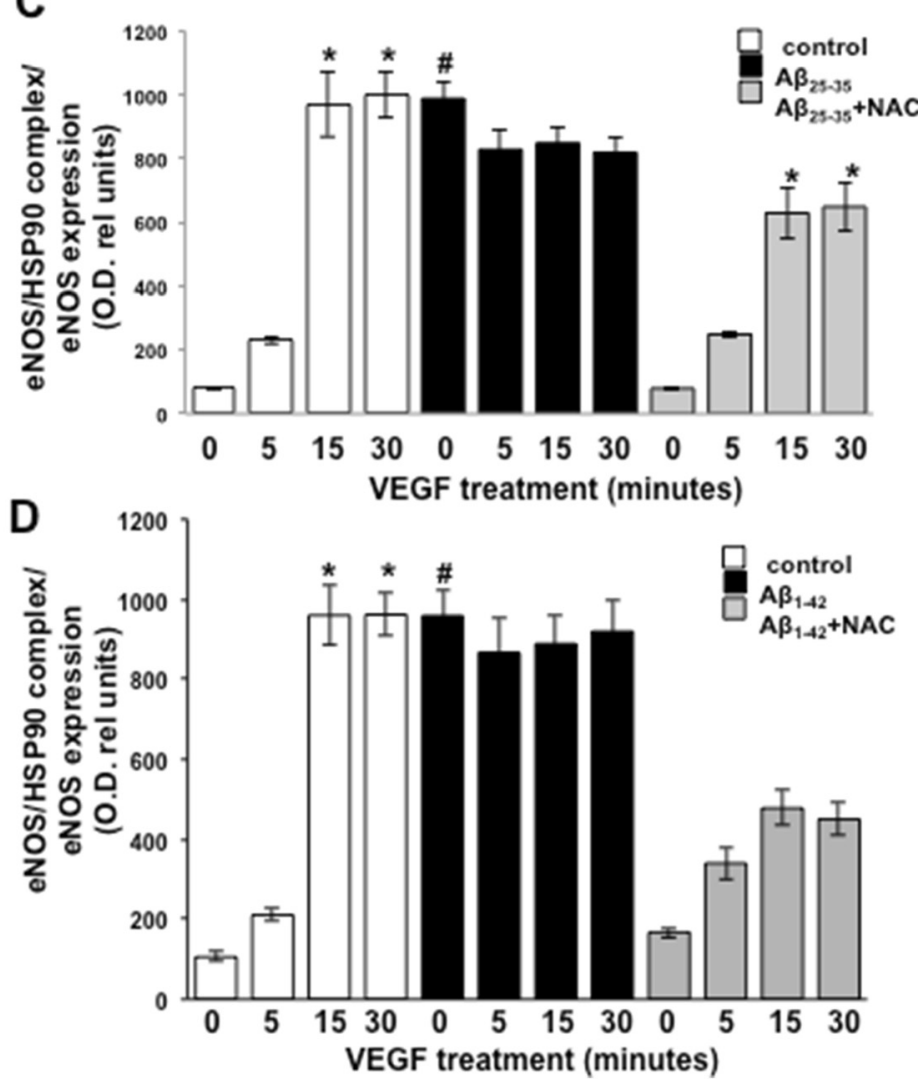

Figure $\mathbf{5}$ Immunoprecipitation analysis showing eNOS/HSP90 complex formation (as in Figure 2) in response to stimulation with 20 ng/ml VEGF of BAECs cultured in the presence of $A \beta_{25-35}(\mathbf{A})$ and $1 \mu \mathrm{MA} \beta_{1-42}$ (B) for $24 \mathrm{~h}$ and in combination with $2 \mathrm{mM}$ NAC. (C-D) The blots were subjected to densitometric analysis, and the obtained data were analyzed for statistical significance in comparison to the data showed in Figure $2 A, B$. $\left({ }^{*} P<0.05\right.$ versus 0 min of each separate treatment group and \#P<0.02 versus 0 min of untreated control cells (white bars), $n=4)$. VEGF, vascular endothelial growth factor; eNOS, endothelial nitric oxide synthase; min, minutes; NAC, N-acetyl-cysteine; Hsp90, heat shock protein 90.

effect on Akt/HSP90. Our results show that both $\mathrm{A} \beta$ peptides block the basal ratio of VEGF-mediated Akt/ HSP90 interaction at $5 \mathrm{~min}$, the critical time point identified earlier as the window for Akt phosphorylation (Figure 9A,C and Figure 10A,C, red boxes). NAC effectively thwarts this abrogation, restoring Akt/HSP90 association to exceed a threshold where Akt activation can occur (Figure 9B,C and Figure 10B,C). To assess statistical significance, the densitometric analysis data are compared to those shown in Figures 9 and 10A,B and the obtained results are plotted in Figures 9 and 10C.

\section{Discussion}

Endothelial production of nitric oxide is critical to the maintenance of vascular tone and the blood brain barrier, as well as to the anti-inflammatory and anti-thrombotic properties of the vascular endothelium [27]. Altered eNOSdependent NO production results in endothelial dysfunction, which is associated with cardiovascular disease and has been shown to play a pathogenic role in $\mathrm{AD}[7,27]$.

In this study, we demonstrated that exogenous administration of the biologically active fragments $A \beta_{25-35}$ and $A \beta_{1-42}$ to cultured endothelial cells results in the production of reactive oxygen species (Figure 3), blockade of agonist-stimulated phosphorylation of eNOS at serine 1179 and decreased NO production (Figure 1). These effects correlated with $A \beta$-induced promotion a constitutive interaction of eNOS with its regulatory partner HSP90 (Figure 2). This correlated with a decrease in the interaction of HSP90 with Akt, the kinase responsible 
A

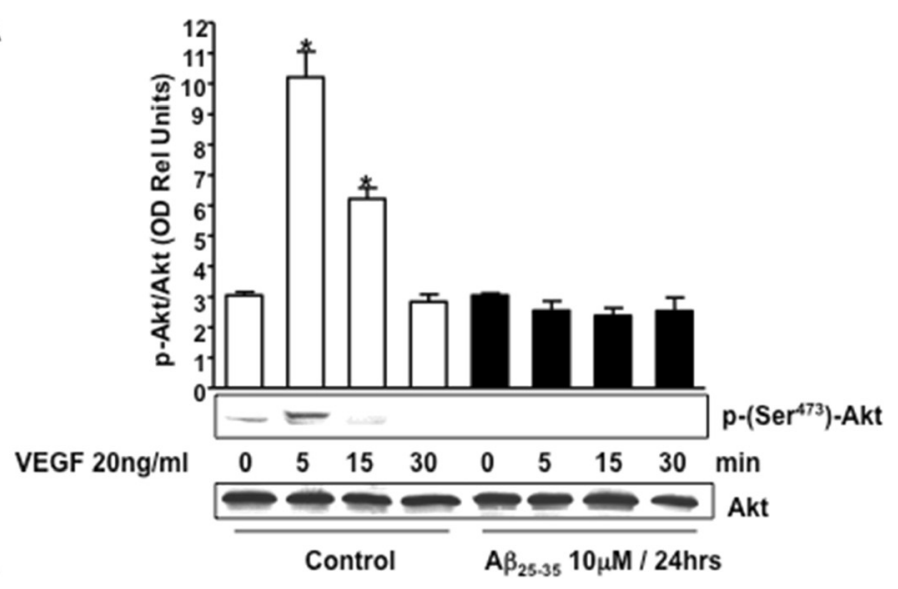

B

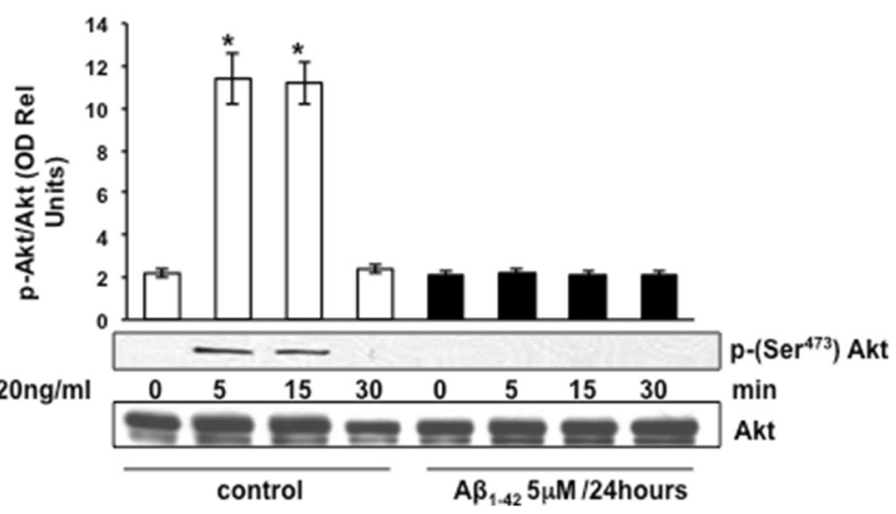

Figure 6 Representative Western blotting and densitometric analysis showing Akt phosphorylation at serine 473 in BAECs after stimulation with VEGF $20 \mathrm{ng} / \mathrm{ml}$ for 0 to $30 \mathrm{~min}$. BAECs were cultured for $24 \mathrm{~h}$ in the presence (black bars) or absence (control, white bars) of $10 \mu \mathrm{M} A \beta_{25-35}$ (A) and $5 \mu \mathrm{M} \mathrm{A} \beta_{1-42}$ (B). Data were analyzed for statistical significance ( ${ }^{*} P<0.01$ versus 0 min control group, $n=3$ ). VEGF, vascular endothelial growth factor.
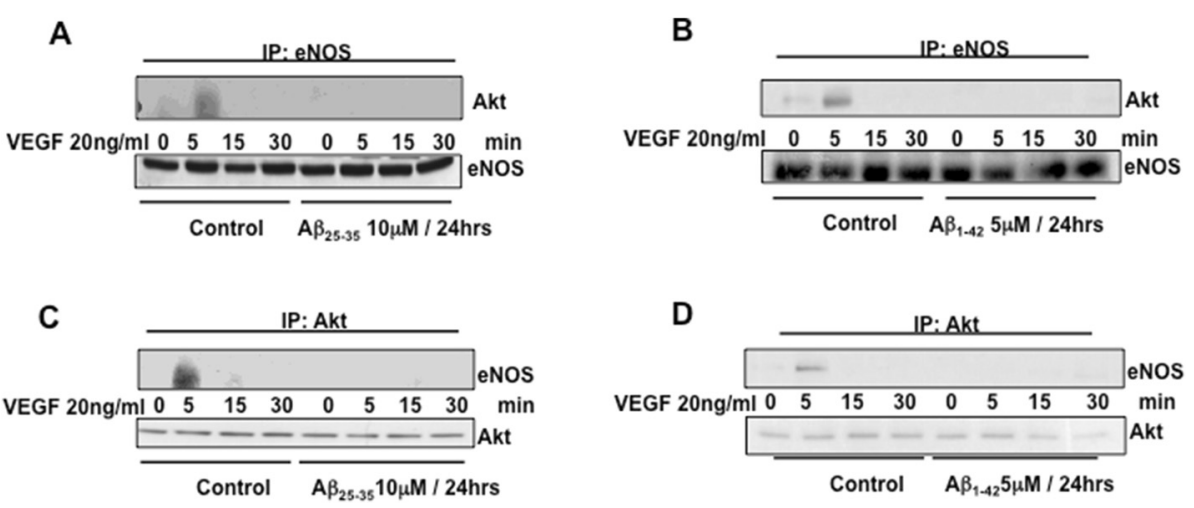

Figure 7 Immunoprecipitation studies showing time-dependent eNOS/Akt complex formation in response to stimulation with $20 \mathrm{ng} / \mathrm{ml}$ VEGF $\left(0 \mathrm{~min}\right.$ ) in BAECs cultured for $24 \mathrm{~h}$ in the presence or absence (control) of $10 \mu \mathrm{M} \mathrm{A} \beta_{25-35}$ (A-C) and $5 \mu \mathrm{M} A \beta_{1-42}$ (B-D). (A-B) Immunoprecipitation was carried-out with anti-eNOS antibody, and the immunoprecipitated proteins were blotted with antibody against anti-Akt. (C-D) Immunoprecipitation was carried-out with anti-Akt antibody, and the immunoprecipitated proteins were blotted with antibody against anti-eNOS. VEGF, vascular endothelial growth factor; eNOS, endothelial nitric oxide synthase; min, minutes. 


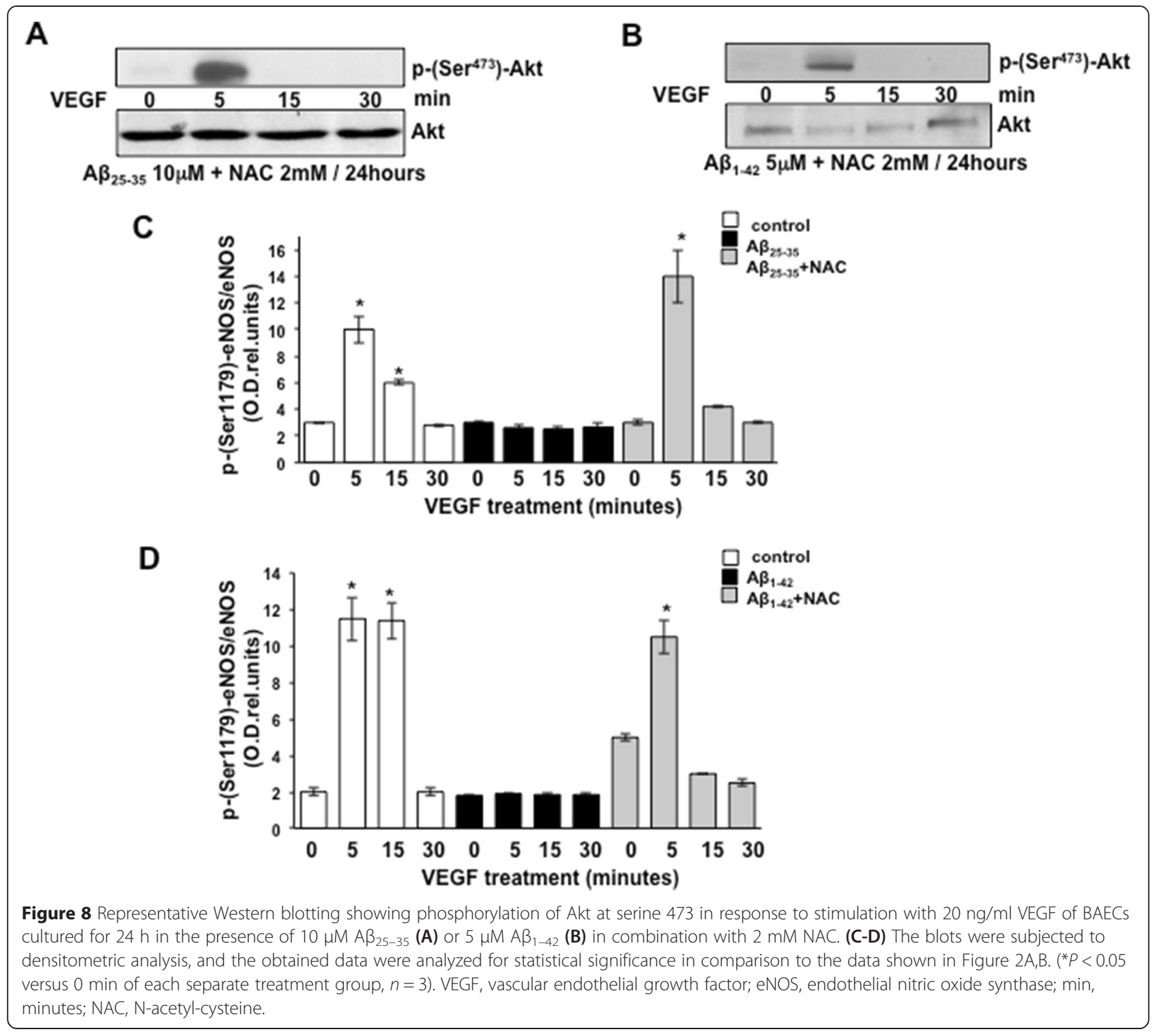

eNOS phosphorylation at Set1179 (Figure 9). These observed alterations appear to be the result of oxidative damage because the concomitant treatment of the cells with the antioxidant $\mathrm{N}$-acetyl cysteine reverts $\mathrm{A} \beta$ effects restoring a normal pattern of eNOS phosphorylation at serine 1179 and interaction with HSP-90 (Figures 4 and 8). Our data demonstrated for the first time an inverse effect of A 3 on HSP90/eNOS interaction and HSP90/Akt interaction. We confirmed that upon stimulation with VEGF, Akt phosphorylates eNOS in an HSP90-dependent manner; synergistically increasing eNOS activity (Figures 1, 6, and 7). Once $A \beta$ is introduced to these conditions, there is a diminished interaction between HSP90 and Akt, suggesting that the chaperone remains bound to eNOS in a manner that facilitates its inability to sufficiently bind Akt to signal its phosphorylation at Ser473 (Figures 9 and 10). Although the partial loss of this interaction could occur from other unexplored mechanisms, such as loss of the overall HSP90 protein level previously demonstrated as an effect of $A \beta$ stimulation [43], it is reasonable to conclude that blocking the effects of $\mathrm{A} \beta$ can restore this interaction. In fact, when treated with NAC, HSP90/ Akt interaction returns to basal levels and the detection of phospho-Akt $\left(\mathrm{Ser}^{473}\right)$ indicate that this kinase overcomes the effects of $A \beta$ in the presence of an antioxidant (Figures 9 and 10).

The results of our study strongly support the growing evidence that vascular dysfunction is involved in the etiology of AD dementia. Indeed, severe vascular changes, such as microvascular degeneration and breakdown of the blood brain barrier, have been demonstrated in $\mathrm{AD}$ patients [44]. In addition, $A \beta$ can be found both in the brain parenchyma and in the cerebral vasculature of $\mathrm{AD}$ patients together with increased presence of monocytes/ 

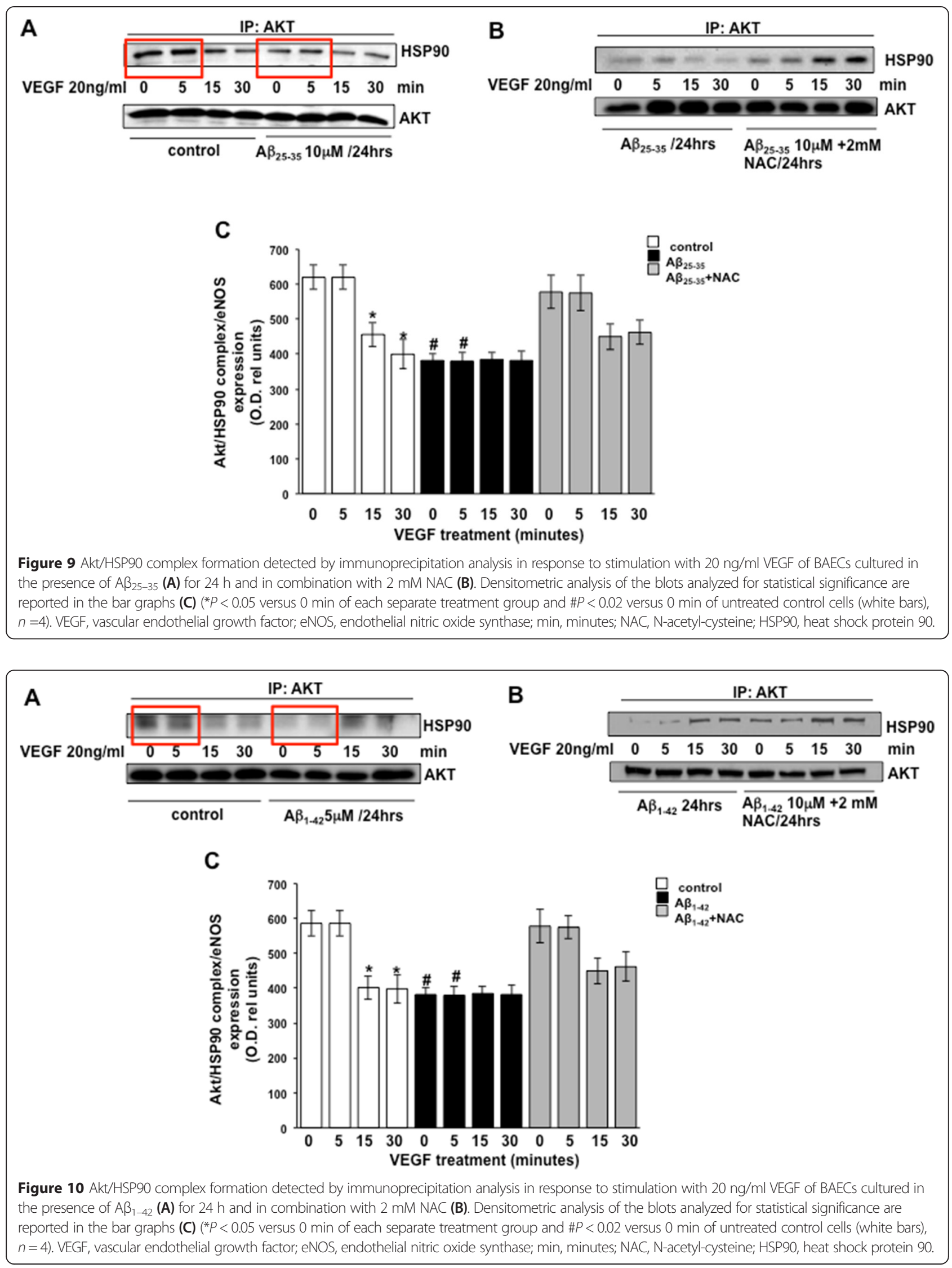
macrophages in the vessel wall and activated microglial cells in the parenchyma $[45,46]$.

To date, attention has been focused on the molecular mechanisms by which $A \beta$ and/or its fragments exert their effect on cells. The assumption that amyloid deposits are typically extracellular accounts for an effect at the level of the plasma membrane, possibly receptor-mediated. However, intracellular $A \beta$ accumulation has been observed in various cell types, including neurons and endothelial cells [47-49]. In particular, it is not clear whether the effect of $A \beta$ on eNOS activity initiates with the extracellular $A \beta$ deposition or results from $A \beta$ intracellular accumulation.

In this respect, reports have shown that internalized $\mathrm{A} \beta$ prevents eNOS from utilizing NADPH [49], a cofactor required for the activity of the enzyme. Furthermore, other studies have shown that over-expression of $A \beta$ in endothelial cells or administration of exogenous (extracellular) $\mathrm{A} \beta$ on isolated vessels, blunts agonist-mediated eNOS activation and its phosphorylation at serine 1177/ $1179[25,26]$. Although these studies provide critical information, it is not clear if the aberrant intracellular production of $A \beta$ peptides is a primary event in endothelial cells or if acute administration of extracellular $A \beta$ represents the condition seen in $\mathrm{AD}$ patients that are chronically exposed to $A \beta$. It is tempting to speculate that both observations may be considered true and complementary. In particular, acute oxidative-independent effects of intraor extracellular $A \beta$ on eNOS activity may be transient, but could result in elevation of reactive oxygen species and in the oxidative-dependent chronic effects that we observe after $24 \mathrm{~h}$ of exposure.

Interestingly, our data show that $\mathrm{A} \beta$ promotes eNOS/ HSP90 complex formation in a constitutive manner, providing a novel and important information. Previous work demonstrated that disruption of HSP90 interaction with eNOS results in inhibition of this enzymatic activity $[22,50]$, therefore, one could expect that in the condition of vascular dysfunction the interaction of eNOS with its chaperone would be inhibited. However, this does not appear to be the case, as has been also shown in a model of diabetes [51]. Several reports have demonstrated enhanced HSP90 expression as part of the cellular response to oxidative stress conditions [52-54]. Specifically, the pathology of $\mathrm{AD}$ is characterized by enhanced heat shock proteins expression and activity in response to aberrant 'misfolded' proteins [55]. Of interest, HSP90 expression is induced by $A \beta$ in glial cells which participate in the $A \beta$ clearance process [56]. Our results demonstrate that $A \beta$ might induce similar effects in endothelial cells. Moreover, HSP90 has been demonstrated to inhibit $\mathrm{O}^{2-}$ production by NOS isoforms $[57,58]$, thus the enhancement of HSP90 interaction with eNOS, as shown by our results (Figure 2), could be a compensatory response to maintain the enzyme in a functional state in oxidative stress conditions when the risk of
eNOS uncoupling is higher. However, this fails to occur, suggesting that other mechanisms are involved in this process and may be critical to the ability of HSP90 to regulate eNOS activity.

The evidence provided by our study extends and supports previous work demonstrating that $A \beta$ promotes vascular dysfunction by impairing eNOS-dependent $\mathrm{NO}$ production. Furthermore, our study underscores the role of oxidative stress in the dysfunctional effects of $A \beta$ on eNOS activity and function.

\section{Competing interests}

The authors declare that they have no competing interests.

\section{Authors' contributions}

FL, VM, TP, MG, and AMM carried out the cultures of ECs and Western blotting detection studies and participated in drafting methods and results. $\mathrm{MBH}$ and MCV participated in the design of the study and performed the statistical analysis. MC, CM, MB, and VM conceived of the study, participated in its design and coordination, and helped to draft the manuscript. All authors read and approved the final manuscript.

\section{Acknowledgements}

This work has been supported by Grant PON a3_00359 2Investiamo nel vostro futuro.

\section{Author details}

'Department of Ophthalmology, Georgia Regents University, Health Sciences Campus, 1120 15th St., Augusta, GA 30912, USA. ²Department of Biology, University of Rome 'Roma Tre', Via Ostiense, 169, Rome 00154, Italy.

${ }^{3}$ Department of Neurology and Laboratory of Neuroscience, IRCCS Istituto Auxologico Italiano, Cusano Milanino 20095, Milan, Italy. ${ }^{4}$ Department of Kinesiology, College of William and Mary, 200 Stadium Dr., Williamsburg, VA 23186, USA. ${ }^{5}$ Vascular Biology Center, Georgia Regents University, 1120 15th St., Augusta, GA 30912, USA. ${ }^{6}$ IRC-FSH, Department of Health Sciences, University of Catanzaro 'Magna Graecia', Catanzaro Complesso 'Ninì Barbieri', Roccelletta di Borgia 88021, Italy. ${ }^{7}$ IRCCS San Raffaele Pisana, Via di Val Cannuta, 247, 00166 Rome, Italy.

Received: 31 December 2014 Accepted: 21 April 2015

Published online: 03 May 2015

\section{References}

1. Octave JN. The precursor of amyloid peptide in Alzheimer disease: a protein with multiple functions. Bull Mem Acad R Med Belg. 2009;164(7-9):181-6. discussion 187-8.

2. De Strooper B, Annaert W. Proteolytic processing and cell biological functions of the amyloid precursor protein. J Cell Sci. 2000;113(Pt 11):1857-70.

3. Small DH, Mok SS, Bornstein JC. Alzheimer's disease and A $\beta$ toxicity: from top to bottom. Nat Rev Neurosci. 2001;2(8):595-8.

4. Hefti F, Goure WF, Jerecic J, Iverson KS, Walicke PA, Krafft GA. The case for soluble Abeta oligomers as a drug target in Alzheimer's disease. Trends Pharmacol Sci. 2013;34(5):261-6.

5. de la Torre JC, Stefano GB. Evidence that Alzheimer's disease is a microvascular disorder: the role of constitutive nitric oxide. Brain Res Brain Res Rev. 2000;34(3):119-36.

6. Kelleher RJ, Soiza RL. Evidence of endothelial dysfunction in the development of Alzheimer's disease: is Alzheimer's a vascular disorder? Am J Cardiovasc Dis. 2013;3(4):197-226.

7. Palmer JC, Tayler HM, Love S. Endothelin-converting enzyme-1 activity, endothelin-1 production, and free radical-dependent vasoconstriction in Alzheimer's disease. J Alzheimers Dis. 2013;36(3):577-87.

8. Cifuentes $D$, Poittevin $M$, Dere $E$, Broquères-You $D$, Bonnin $P$, Benessiano J, et al. Hypertension accelerates the progression of Alzheimer-like pathology in a mouse model of the disease. Hypertension. 2015;65(1):218-24.

9. Ríos JA, Cisternas P, Arrese M, Barja S, Inestrosa NC. Is Alzheimer's disease related to metabolic syndrome? A Wnt signaling conundrum. Prog Neurobiol. 2014;121:125-46. 
10. de la Torre JC, Aliev G. Inhibition of vascular nitric oxide after rat chronic brain hypoperfusion: spatial memory and immunocytochemical changes. J Cereb Blood Flow Metab. 2005;25(6):663-72.

11. de la Torre JC, Pappas BA, Prevot V, Emmerling MR, Mantione K. Fortin Tet al. Hippocampal nitric oxide upregulation precedes memory loss and A beta 1-40 accumulation after chronic brain hypoperfusion in rats. Neurol Res. 2003;25(6):635-41.

12. Law A, Gauthier S, Quirion R. Neuroprotective and neurorescuing effects of isoform-specific nitric oxide synthase inhibitors, nitric oxide scavenger, and antioxidant against beta-amyloid toxicity. Br J Pharmacol. 2001;133(7):1114-24.

13. Paris D, Town T, Mori T, Parker TA, Humphrey J, Mullan M. Soluble beta-amyloid peptides mediate vasoactivity via activation of a pro-inflammatory pathway. Neurobiol Aging. 2000;21(2):183-97.

14. Lin AJ, Liu G, Castello NA, Yeh JJ, Rahimian R, Lee G, et al. Optical imaging in an Alzheimer's mouse model reveals amyloid-dependent vascular impairment. Neurophotonics. 2014;1(1):011005.

15. Austin SA, Santhanam AV, Hinton DJ, Choi DS, Katusic ZS. Endothelial nitric oxide deficiency promotes Alzheimer's disease pathology. J Neurochem. 2013;127(5):691-700

16. Sessa WC. Regulation of endothelial derived nitric oxide in health and disease. Mem Inst Oswaldo Cruz. 2005:100 Suppl 1:15-8.

17. Fulton D, Gratton JP, Sessa WC. Post-translational control of endothelial nitric oxide synthase: why isn't calcium/calmodulin enough? J Pharmacol Exp Ther. 2001;299(3):818-24.

18. Fleming I, Busse R. Molecular mechanisms involved in the regulation of the endothelial nitric oxide synthase. Am J Physiol Regul Integr Comp Physiol. 2003;284(1):R1-12

19. Kone BC, Kuncewicz T, Zhang W, Yu ZY. Protein interactions with nitric oxide synthases: controlling the right time, the right place, and the right amount of nitric oxide. Am J Physiol Renal Physiol. 2003;285(2):F178-90.

20. Mount PF, Kemp BE, Power DA. Regulation of endothelial and myocardial NO synthesis by multi-site eNOS phosphorylation. J Mol Cell Cardiol. 2007;42(2):271-9.

21. Chatterjee A, Black SM, Catravas JD. Endothelial nitric oxide (NO) and its pathophysiologic regulation. Vascul Pharmacol. 2008;49(4-6):134-40.

22. Garcia-Cardena G, Fan R, Shah V, Sorrentino R, Cirino G, Papapetropoulos A, et al. Dynamic activation of endothelial nitric oxide synthase by Hsp90. Nature. 1998;392(6678):821-4

23. Harris MB, Ju H, Venema VJ, Blackstone M, Venema RC. Role of heat shock protein 90 in bradykinin-stimulated endothelial nitric oxide release. Gen Pharmacol. 2000;35(3):165-70

24. Brouet A, Sonveaux P, Dessy C, Balligand JL, Feron O. Hsp90 ensures the transition from the early $\mathrm{Ca} 2+-$ dependent to the late phosphorylation-dependent activation of the endothelial nitric-oxide synthase in vascular endothelial growth factor-exposed endothelial cells. J Biol Chem. 2001;276(35):32663-9.

25. Gentile MT, Vecchione C, Maffei A, Aretini A, Marino G, Poulet R, et al. Mechanisms of soluble beta-amyloid impairment of endothelial function. J Biol Chem. 2004;279(46):48135-42

26. Suhara T, Magrané J, Rosen K, Christensen R, Kim HS, Zheng B, et al. Abeta42 generation is toxic to endothelial cells and inhibits eNOS function through an Akt/ GSK-3beta signaling-dependent mechanism. Neurobiol Aging. 2003:24(3):437-51.

27. Forstermann $U$, Munzel $T$. Endothelial nitric oxide synthase in vascular disease: from marvel to menace. Circulation. 2006:113(13):1708-14.

28. Cook S. Coronary artery disease, nitric oxide and oxidative stress: the 'Yin-Yang' effect - a Chinese concept for a worldwide pandemic. Swiss Med Wkly. 2006;136(7-8):103-13

29. Da Ros R, Assaloni R, Ceriello A. Antioxidant therapy in diabetic complications: what is new? Curr Vasc Pharmacol. 2004;2(4):335-41.

30. Marchesi C, Ebrahimian T, Angulo O, Paradis P, Schiffrin EL. Endothelial nitric oxide synthase uncoupling and perivascular adipose oxidative stress and inflammation contribute to vascular dysfunction in a rodent model of metabolic syndrome. Hypertension. 2009;54(6):1384-92.

31. Lamoke F, Ripandelli G, Webster S, Montemari A, Maraschi A, Martin P, et al. Loss of thioredoxin function in retinas of mice overexpressing amyloid beta. Free Radic Biol Med. 2012:53(3):577-88.

32. Butterfield DA. Amyloid beta-peptide (1-42)-induced oxidative stress and neurotoxicity: implications for neurodegeneration in Alzheimer's disease brain. A review Free Radic Res. 2002;36(12):1307-13.

33. Nunomura A, Castellani RJ, Zhu X, Moreira PI, Perry G, Smith MA Involvement of oxidative stress in Alzheimer disease. J Neuropathol Exp Neurol. 2006;65(7):631-41.
34. Stine Jr WB, Dahlgren KN, Krafft GA, LaDu MJ. In vitro characterization of conditions for amyloid- $\beta$ peptide oligomerization and fibrillogenesis. J Biol Chem. 2003;278:11612-22.

35. Ishii K, Sheng H, Warner TD, Förstermann U, Murad F. A simple and sensitive bioassay method for detection of EDRF with RFL-6 rat lung fibroblasts. Am J Physiol. 1991;261(2 Pt 2):H598-603.

36. Harris MB, Bartoli M, Sood SG, Matts RL, Venema RC. Direct interaction of the cell division cycle 37 homolog inhibits endothelial nitric oxide synthase activity. Circ Res. 2006;98(3):335-41.

37. Bartoli M, Gu X, Tsai NT, Venema RC, Brooks SE, Marrero MB, et al. Vascular endothelial growth factor activates STAT proteins in aortic endothelial cells. J Biol Chem. 2000;275(43):33189-92.

38. Bartoli M, Platt D, Lemtalsi T, Gu X, Brooks SE, Marrero MB, et al. VEGF differentially activates STAT3 in microvascular endothelial cells. FASEB J. 2003;17(11):1562-4.

39. Liang $H$, Zhang $Y$, Shi $X$, Wei T, Lou J. Role of Notch-1 signaling pathway in PC12 cell apoptosis induced by amyloid beta-peptide (25-35). Neural Regen Res. 2014;9(13):1297-302

40. Roher AE, Chaney MO, Kuo YM, Webster SD, Stine WB, Haverkamp LJ, et al. Morphology and toxicity of Abeta-(1-42) dimer derived from neuritic and vascular amyloid deposits of Alzheimer's disease. J Biol Chem. 1996;271(34):20631-5.

41. Miao RQ, Fontana J, Fulton D, Lin MI, Harrison KD, Sessa WC. Dominant-negative Hsp90 reduces VEGF-stimulated nitric oxide release and migration in endothelial cells. Arterioscler, Thromb, Vasc Biol. 2008;28(1):105-11.

42. Shin E, Yeo E, Lim J, Chang YH, Park H, Shim E, et al. Nitrooleate mediates nitric oxide synthase activation in endothelial cells. Lipids. 2014;49(5):457-66

43. Chiu WT, Shen SC, Yang LY, Chow JM, Wu CY, Chen YC. Inhibition of HSP90-dependent telomerase activity in amyloid beta-induced apoptosis of cerebral endothelial cells. J Cell Physiol. 2011;226(8):2041-51.

44. Silvestrini M, Pasqualetti P, Baruffaldi R, Bartolini M, Handouk Y, Matteis M, et al. Cerebrovascular reactivity and cognitive decline in patients with Alzheimer disease. Stroke. 2006:37(4):1010-5.

45. Maat-Schieman ML, van Duinen SG, Rozemuller AJ, Haan J, Roos RA. Association of vascular amyloid beta and cells of the mononuclear phagocyte system in hereditary cerebral hemorrhage with amyloidosis (Dutch) and Alzheimer disease. J Neuropathol Exp Neurol. 1997;56(3):273-84.

46. Wisniewski HM, Vorbrodt AW, Wegiel J. Amyloid angiopathy and blood-brain barrier changes in Alzheimer's disease. Ann N Y Acad Sci. 1997:826:161-72.

47. Turner RS, Suzuki N, Chyung AS, Younkin SG, Lee VM. Amyloids beta40 and beta42 are generated intracellularly in cultured human neurons and their secretion increases with maturation. J Biol Chem. 1996;271(15):8966-70.

48. Wild-Bode C, Yamazaki T, Capell A, Leimer U, Steiner H, Ihara Y, et al. Intracellular generation and accumulation of amyloid beta-peptide terminating at amino acid 42. J Biol Chem. 1997;272(26):16085-8.

49. Venturini G, Colasanti M, Persichini T, Fioravanti E, Ascenzi P, Palomba L, et al. Beta-amyloid inhibits NOS activity by subtracting NADPH availability. FASEB J. 2002;16(14):1970-2.

50. Xu H, Shi Y, Wang J, Jones D, Weilrauch D, Ying $R$, et al. A heat shock protein 90 binding domain in endothelial nitric-oxide synthase influences enzyme function. J Biol Chem. 2007;282(52):37567-74.

51. Fulton D, Harris MB, Kemp BE, Venema RC, Marrero MB, Stepp DW. Insulin resistance does not diminish eNOS expression, phosphorylation, or binding to HSP-90. Am J Physiol Heart Circ Physiol. 2004;287(6):H2384-93.

52. Dihazi $H$, Asif AR, Agarwal NK, Doncheva Y, Müller GA. Proteomic analysis of cellular response to osmotic stress in thick ascending limb of Henle's loop (TALH) cells. Mol Cell Proteomics. 2005:4(10):1445-58.

53. Hojlund K, Wrzesinski K, Larsen PM, Fey SJ, Roepstorff P, Handberg A, et al. Proteome analysis reveals phosphorylation of ATP synthase beta-subunit in human skeletal muscle and proteins with potential roles in type 2 diabetes. J Biol Chem. 2003;278(12):10436-42.

54. Vega $\mathrm{VL}$, De Maio $\mathrm{A}$. Increase in phagocytosis after geldanamycin treatment or heat shock: role of heat shock proteins. J Immunol. 2005;175(8):5280-7.

55. Hoozemans JJ, Stieler J, van Haastert ES, Veerhuis R, Rozemuller AJ, Baas F, et al. The unfolded protein response affects neuronal cell cycle protein expression: implications for Alzheimer's disease pathogenesis. Exp Gerontol. 2006;41(4):380-6. 
56. Kakimura J, Stieler J, van Haastert ES, Veerhuis R, Rozemuller AJ, Baas F, et al. Microglial activation and amyloid-beta clearance induced by exogenous heat-shock proteins. FASEB J. 2002;16(6):601-3.

57. Song Y, Zweier JL, Xia Y. Determination of the enhancing action of HSP90 on neuronal nitric oxide synthase by EPR spectroscopy. Am J Physiol Cell Physiol. 2001;281(6):C1819-24.

58. Scroggins BT, Neckers L. Just say NO: nitric oxide regulation of Hsp90. EMBO Rep. 2009;10(10):1093-4.

Submit your next manuscript to BioMed Central and take full advantage of:

- Convenient online submission

- Thorough peer review

- No space constraints or color figure charges

- Immediate publication on acceptance

- Inclusion in PubMed, CAS, Scopus and Google Scholar

- Research which is freely available for redistribution 